\title{
Separation of Rh(III) from the Mixed Chloride Solutions Containing Pt(IV) and Pd(II) by Extraction with Alamine336
}

\author{
Panpan Sun, Myungho Lee, ${ }^{\dagger}$ and Manseung Lee* \\ Department of Advanced Materials Science \&Engineering, Mokpo National University, Chonnam 534-729, Korea \\ *E-mail:mslee@mokpo.ac.kr \\ ${ }^{\dagger}$ Nuclear Chemistry Research Division, Korea Atomic Energy Research Institute, P.O. Box 105, Yuseong, \\ Daejeon 305-353 Korea \\ Received April 2, 2010, Accepted May 11, 2010
}

\begin{abstract}
Solvent extraction experiments of $\mathrm{Pt}(\mathrm{IV}), \mathrm{Pd}(\mathrm{II})$ and $\mathrm{Rh}$ (III) by Alamine 336 were performed from the mixed chloride solutions. In the $\mathrm{HCl}$ concentration range from 1 to $5 \mathrm{M}$, most of Pt and Pd were extracted from the mixed solutions. However, the extraction percentage of $\mathrm{Rh}$ was much smaller than that of $\mathrm{Pt}$ and Pd. Lower concentration of Alamine 336 in strong $\mathrm{HCl}$ solution led to higher separation factor of $\mathrm{Rh}$ from $\mathrm{Pt}$ and $\mathrm{Pd}$. Adding $\mathrm{SnCl}_{2}$ to the mixed solutions increased the extraction percentage of $\mathrm{Rh}$, while the extraction percentage of $\mathrm{Pt}$ and $\mathrm{Pd}$ was little affected. Our results showed that selective separation of Rh or coextraction of the three platinum group metals from the mixed solution would be possible by adjusting the extraction conditions.
\end{abstract}

Key Words: Separation, Platinum, Palladium, Rhodium, Alamine336

\section{Introduction}

Platinum group metals(PGMs) are extensively used in automobile, chemical and electronics industry owing to their specific physical and chemical properties. Among PGMs, platinum, palladium and rhodium are used in automobile catalysts to reduce the emission level from the exhaust gas and the automobile industry consumes PGMs in a great measure. ${ }^{1}$ The high cost of recovery and limited resources of these metals make it necessary to recover the metals from industry waste. Considering the difficulties related with the separation and purification of PGMs, it is important to find an effective separation process to recover these metals with high purity. ${ }^{1}$ According to the published literatures, ion exchange and solvent extraction have been widely employed to separate and recover them. Among Pt, Pd and Rh, extraction of Rh is the most difficult owing to its intricate chemical properties in chloride solution. ${ }^{2}$ Rhodium has seven existence forms of aqua-chloro complexes from $\left[\mathrm{Rh}\left(\mathrm{H}_{2} \mathrm{O}\right)_{6}{ }^{3+}\right]$ to $\left[\mathrm{RhCl}_{6}^{3-}\right]^{2}$. The highly charged octanedral complexes are difficult to extract owing to steric effects. ${ }^{2}$

Various neutral and anionic extractants have been used in the extraction of Pt, Pd and Rh from chloride solution. ${ }^{2-9}$ In the extraction of PGMs from chloride solution, anionic extractants are better than neutral extractants when $\mathrm{HCl}$ concentration is not strong. With the increase of $\mathrm{HCl}$ concentration, the fraction of undissociated metal acid complex increases and neutral extractants are better to extract these neutral complexes at high $\mathrm{HCl}$ concentration.

Alamine336 (Tertiary amine, $\mathrm{R}_{3} \mathrm{~N}, \mathrm{R}=\mathrm{CH}_{3}\left(\mathrm{CH}_{2}\right)_{7}$ ) is a sort of anionic extractant and has been widely used in extracting various metal ions ${ }^{2,10-13}$ In this study, we chose Alamine336 to separate $\mathrm{Rh}$ (III) from the mixed hydrochloride solutions containing Pd and Pt. The optimum conditions for the separation of $\mathrm{Rh}$ from $\mathrm{Pd}$ and $\mathrm{Pt}$ were investigated by varying $\mathrm{HCl}$ and $\mathrm{Ala}-$ mine336 concentration. It has been reported that $\mathrm{SnCl}_{2}$ has a positive effect on the extraction of Rh. Effect of adding tin chloride on the separation of $\mathrm{Rh}$ from the mixed chloride solution was also investigated.

\section{Experimental}

Stock solutions of $\mathrm{PtCl}_{4}, \mathrm{PdCl}_{2}, \mathrm{RhCl}_{3}$ and $\mathrm{SnCl}_{2}$ were prepared by dissolving the necessary amount of the metal chlorides in doubly distilled water. Reagent grade of $\mathrm{PtCl}_{4}, \mathrm{PdCl}_{2}, \mathrm{RhCl}_{3}$, and $\mathrm{SnCl}_{2}$ was used in preparing these solutions. The acidity of the solution was adjusted by adding reagent $\mathrm{HCl}(36 \%)$ solution.

Alamine336 (Henkel Corp.) was used without further purification. Equal volume of Alamine 336 and $\mathrm{HCl}$ were mixed according to reaction (1) to form Alamine 336 salt $\left(\mathrm{R}_{3} \mathrm{NHCl}\right)$ which takes part in the solvent extraction of metals. ${ }^{3,10,11}$ Alamine336 salt was diluted with toluene.

$$
\mathrm{R}_{3} \mathrm{~N}_{\text {org }}+\mathrm{HCl}=\mathrm{R}_{3} \mathrm{NHCl}_{\text {org }}
$$

In this reaction, subscript org represents organic phase.

Throughout the solvent extraction experiments in our study, freshly prepared aqueous solutions were used. Equal volume $(20 \mathrm{~mL})$ of aqueous and organic phase was mixed in a $100 \mathrm{~mL}$ screwed cap bottle and shaken for 30 mins with a wrist action shaker. The aqueous phase was separated after settling the mixture. All the extraction experiments were carried out at ambient temperature. The concentration of metal in the aqueous phase was measured by ICP-OES (Spectro arcos). The concentration of metal in the organic phase was obtained from mass balance.

\section{Results and Discussion}

Effect of Alamine336 and $\mathrm{HCl}$ concentration on the extraction of metals from the mixed solution of Pt (IV) and Pd (II). Fig. 1 shows the effect of Alamine 336 and $\mathrm{HCl}$ concentration 

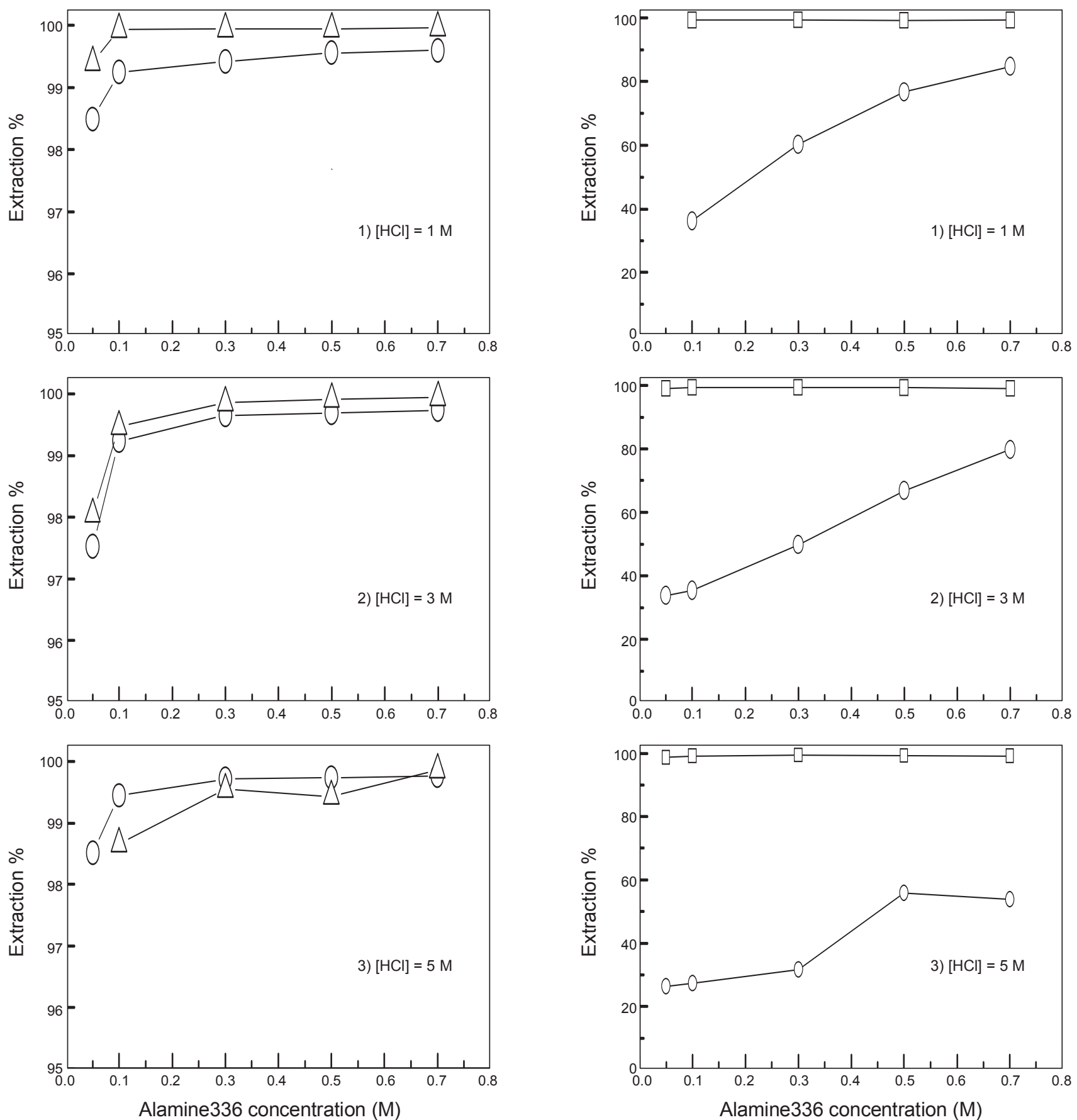

Figure 1. Effect of Alamine 336 and $\mathrm{HCl}$ concentration on the extraction of metals from the mixed solutions of Pt(IV) and Pd(II). ([PtCl 4$]_{\text {total }}=$ $\left.0.001 \mathrm{M},\left[\mathrm{PtCl}_{2}\right]_{\text {total }}=0.001 \mathrm{M}\right)(-\mathrm{O}-: \mathrm{Pt}(\mathrm{IV}),-\triangle: \mathrm{Pt}(\mathrm{II}))$.

on the extraction of metals from the mixed solutions of $\mathrm{Pt}$ (IV) and Pd (II). In these experiments, the initial concentration of Pt and Pd was kept at $0.001 \mathrm{M}$. The extraction percentage of both metals increased with the increase of Alamine336 concentration. When Alamine 336 concentration was higher than $0.3 \mathrm{M}, \mathrm{Pt}$ and Pd were almost completely extracted by Alamine336. When $\mathrm{HCl}$ concentration is 1 and $3 \mathrm{M}$, extraction percentage of $\mathrm{Pd}$ was higher than that of $\mathrm{Pt}$, while extraction percentage of $\mathrm{Pt}$ was higher than that of $\mathrm{Pd}$ at $5 \mathrm{M} \mathrm{HCl}$. In our experimental range, $\mathrm{Pt}$ and Pd were well extracted by Alamine336 and it would be

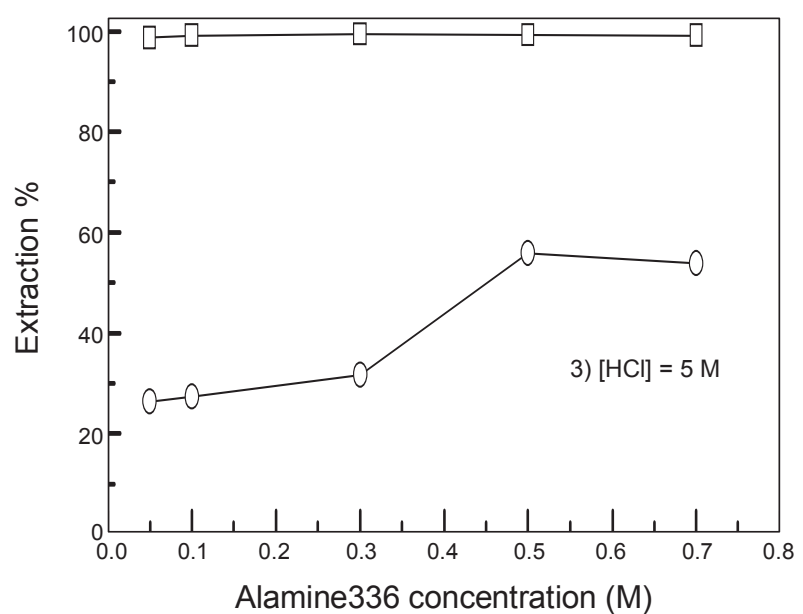

Figure 2. Effect of Alamine 336 and $\mathrm{HCl}$ concentration on the extraction of metals from the mixed solutions of $\mathrm{Pt}(\mathrm{IV})$ and $\mathrm{Rh}(\mathrm{III})$. ([PtCl 4$]_{\text {total }}=$ $\left.0.001 \mathrm{M},\left[\mathrm{RhCl}_{3}\right]_{\text {total }}=0.001 \mathrm{M}\right)(-\square-: \mathrm{Pt}(\mathrm{IV}),-\mathrm{O}-\mathrm{Rh}(\mathrm{III}))$.

difficult to separate these two metals by solvent extraction with Alamine336 alone. The extraction reaction of Pt and Pd by Alamine 336 can be represented as:

$$
\begin{aligned}
& \mathrm{PtCl}_{6}{ }^{2-}+2 \mathrm{R}_{3} \mathrm{NHCl}_{\text {org }}=\mathrm{PtCl}_{6}\left(\mathrm{R}_{3} \mathrm{NH}\right)_{2, \text { org }}+2 \mathrm{Cl}^{-} \\
& \mathrm{PdCl}_{4}{ }^{2-}+2 \mathrm{R}_{3} \mathrm{NHCl}_{\text {org }}=\mathrm{PdCl}_{4}\left(\mathrm{R}_{3} \mathrm{NH}\right)_{2, \text { org }}+2 \mathrm{Cl}^{-}
\end{aligned}
$$

According to the published literatures, ${ }^{5,6}$ the extraction of platinum will decrease at higher concentration of hydrochloric acid 


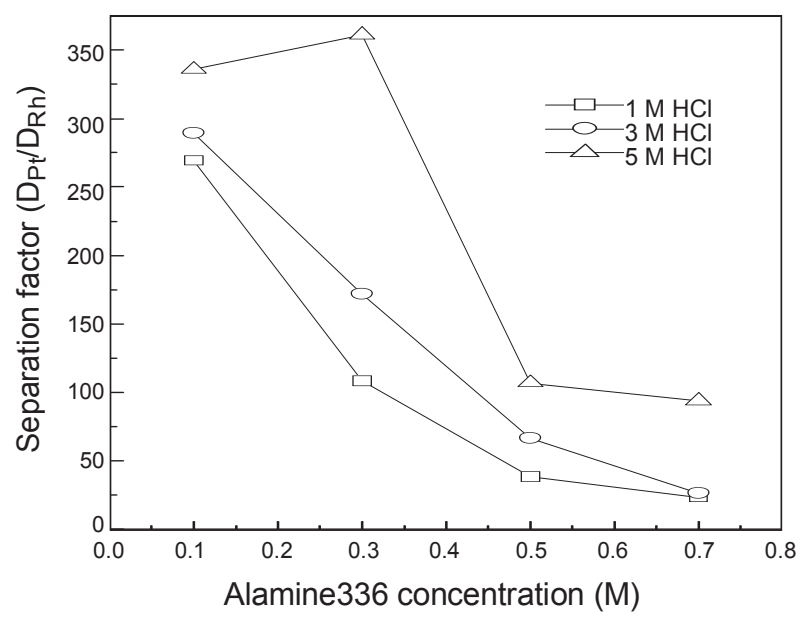

Figure 3. Separation factor for $\mathrm{Pt}(\mathrm{IV})$ and $\mathrm{Rh}(\mathrm{III})$ at different $\mathrm{HCl}$ concentration with respect to Alamine336 concentration. $\left(\left[\mathrm{PtCl}_{4}\right]_{\text {total }}=\right.$ $\left.0.001 \mathrm{M},\left[\mathrm{RhCl}_{3}\right]_{\text {total }}=0.001 \mathrm{M}\right)$.

owing to the mass action effect of chloride ions. In our study, the concentration of $\mathrm{HCl}$ was not very high and the effect of $\mathrm{HCl}$ concentration on the extraction of platinum was not obvious. The extraction results in Fig. 1 imply that both Pt and Pd can be simultaneously extracted by Alamine 336 by adjusting $\mathrm{HCl}$ and Alamine 336 concentration.

Fig. 2 shows the effect of Alamine 336 and $\mathrm{HCl}$ concentration on the extraction of metals from the mixed solutions of Pt(IV) and $\mathrm{Rh}(\mathrm{III})$. The initial concentration of $\mathrm{Pt}$ and $\mathrm{Rh}$ was kept at $0.001 \mathrm{M}$. It is seen in Fig. 2 that most of Pt was extracted by Alamine336 in our experimental ranges. However, the extraction of $\mathrm{Rh}$ depended on $\mathrm{HCl}$ and Alamine 336 concentration. Extraction percentage of $\mathrm{Rh}$ decreased with the increase of $\mathrm{HCl}$ concentration when Alamine336 concentration was constant. Separation factor between $\mathrm{Pt}$ and $\mathrm{Rh}$ was defined as

$$
\text { separation factor }=\frac{D_{\mathrm{Pt}}}{D_{\mathrm{Rh}}}
$$

Variation of the separation factor with extraction conditions is represented in Fig. 3. According to this figure, the separation factor between $\mathrm{Pt}$ and $\mathrm{Rh}$ decreased with the increase of Alamine 336 concentration and with the decrease of $\mathrm{HCl}$ concentration. The variation of separation factor is due to the fact that the extraction percentage of Pt was nearly constant while that of $\mathrm{Rh}$ increased with increasing Alamine336 concentration as shown in Fig. 2. Considering that the value of separation factor was relatively large, it may be concluded that separation of $\mathrm{Rh}$ from $\mathrm{Pt}$ is possible at low concentration of Alamine 336 in strong $\mathrm{HCl}$ solution.

Fig. 4 shows the effect of Alamine 336 and $\mathrm{HCl}$ concentration on the extraction of metals from the mixed solutions of Pd(II) and $\mathrm{Rh}$ (III). The initial concentration of Pd and $\mathrm{Rh}$ was kept at $0.001 \mathrm{M}$. Extraction percentage of Pd was more than $99 \%$ in our experimental range. However, the extraction behavior of Rh was similar to those obtained from the mixed solution with Pt. Extraction percentage of Rh increased with increasing Alamine336 concentration and with decreasing $\mathrm{HCl}$ concentration.
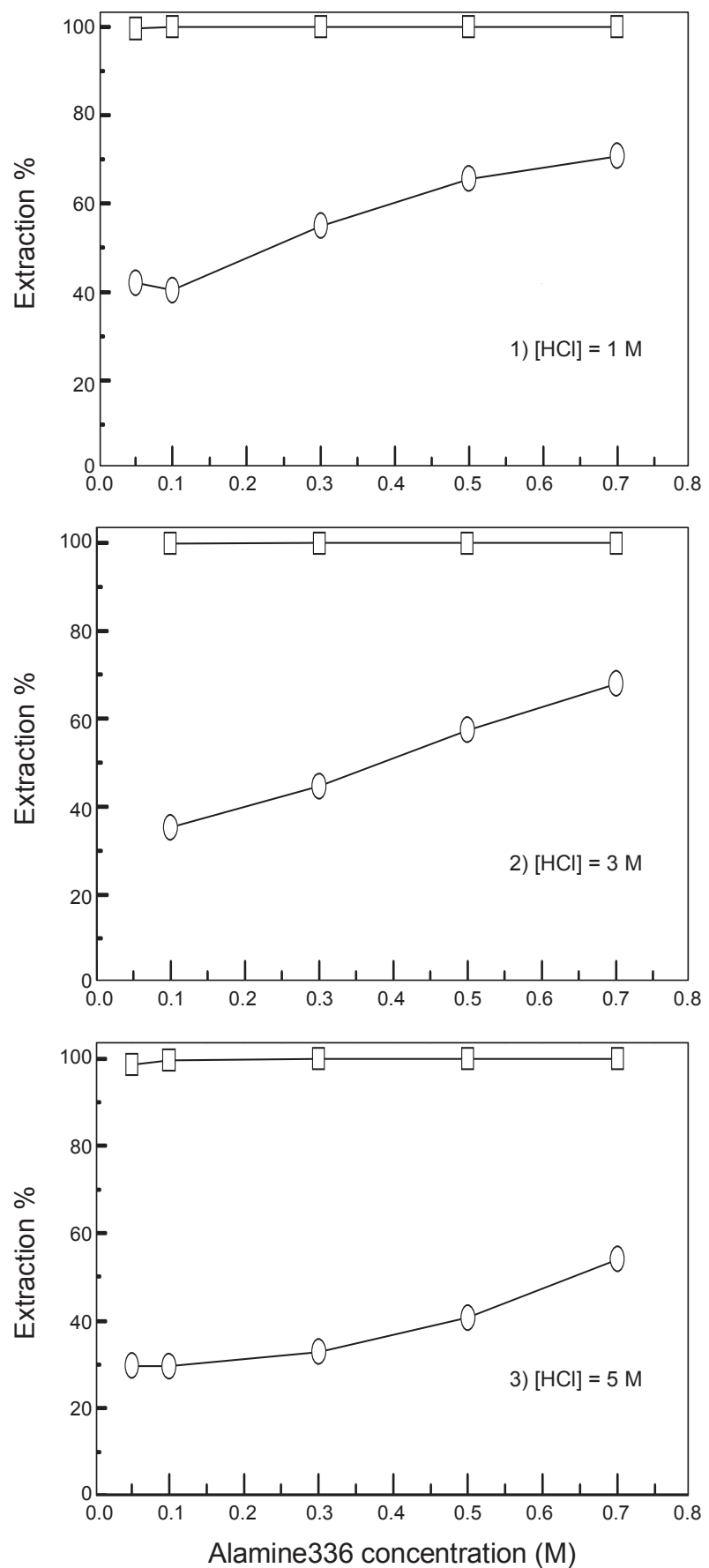

Figure 4. Effect of Alamine 336 and $\mathrm{HCl}$ concentration on the extraction of metals from the mixed solutions of $\mathrm{Pd}(\mathrm{II})$ and $\mathrm{Rh}(\mathrm{III})$. ([PtCl 2$]_{\text {total }}=$ $\left.0.001 \mathrm{M},\left[\mathrm{RhCl}_{3}\right]_{\text {total }}=0.001 \mathrm{M}\right)(-\square-\mathrm{Pd}(\mathrm{II}),-\mathrm{O}-\mathrm{Rh}(\mathrm{III}))$.

Fig. 5 represents the variation of the separation factor between $\mathrm{Pd}$ and $\mathrm{Rh}$. In this figure, separation factor was defined as the ratio of the distribution coefficient of Pd to that of Rh, i.e., $\mathrm{D}_{\mathrm{Pd}} /$ $\mathrm{D}_{\mathrm{Rh}}$. Separation factor decreased with increasing Alamine336 concentration. Higher separation factor was obtained with stronger $\mathrm{HCl}$ concentration. The drop rate of separation factor with Alamine336 concentration became steeper when $\mathrm{HCl}$ concentration became stronger. The maximum value of separation factor between Pd and Rh obtained in this study was around 4000, which is much higher than that between Pt and Rh. Separa- 


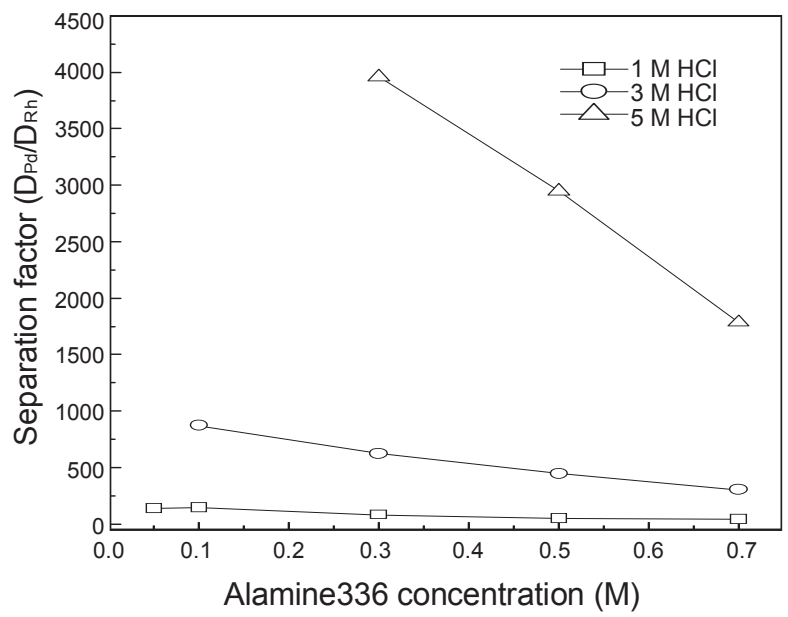

Figure 5. Separation factor for $\mathrm{Pd}(\mathrm{II})$ and $\mathrm{Rh}(\mathrm{III})$ at different $\mathrm{HCl}$ concentration with respect to Alamine336 concentration. $\left(\left[\mathrm{PtCl}_{2}\right]_{\text {total }}=\right.$ $\left.0.001 \mathrm{M},\left[\mathrm{RhCl}_{3}\right]_{\text {total }}=0.001 \mathrm{M}\right)$.

tion of Rh and Pd would be easier than separation of Rh and Pt.

Effect of Alamine 336 and $\mathrm{HCl}$ concentration on the extraction of metals from the mixed solution of $\mathrm{Rh}(\mathrm{III}), \mathrm{Pt}(\mathrm{IV})$ and Pd(II). Separation experiments were performed from the mixed solution of $\mathrm{Rh}(\mathrm{III}), \mathrm{Pt}(\mathrm{IV})$ and $\mathrm{Pd}(\mathrm{II})$. The concentration of these three metals was kept at $0.001 \mathrm{M}$ and the results are shown in Fig. 6. Most of Pt and Pd were extracted in our experimental range, while the extraction percentage of $\mathrm{Rh}$ depended on the extraction conditions. The extraction percentage of $\mathrm{Rh}$ increased with the increase of Alamine 336 concentration at the same $\mathrm{HCl}$ concentration. When Alamine336 concentration was same, the extraction percentage of $\mathrm{Rh}$ increased with the decrease of $\mathrm{HCl}$ concentration. Rhodium is the most expensive of the platinum group metals. Therefore, it is economical to separate preferentially rhodium from the platinum group metals. According to Fig. 6, it is possible to separate $\mathrm{Rh}$ from Pt and Pd by extracting these two metals with Alamine336. For the purpose of isolating rhodium, high concentration of $\mathrm{HCl}$ is favorable.

Some studies have reported that adding $\mathrm{SnCl}_{2}$ to the rhodium solution increased the extraction percentage of Rh by Kelex100, Cyanex 921 and TBP owing to the reducing action of $\mathrm{Sn}(\mathrm{II}){ }^{4-6}$ In order to investigate the effect of adding $\mathrm{SnCl}_{2}$ on the separation of $\mathrm{Rh}$ from the mixed solution, $\mathrm{SnCl}_{2}$ was added to the mixed solution of $\mathrm{Rh}, \mathrm{Pt}$ and $\mathrm{Pd}$. In these mixed solution, the concentration of the three platinum group metals was kept at $0.001 \mathrm{M}$, while $\mathrm{SnCl}_{2}$ concentration was controlled to $0.01 \mathrm{M}$. The extraction behavior of the platinum group metals together with tin is shown in Fig. 7. In our experimental range, most of Pt, $\mathrm{Pd}$ and Sn were extracted by Alamine336. The extraction percentage of $\mathrm{Rh}$ was from 40 to $80 \%$ depending on the concentration of $\mathrm{HCl}$ and Alamine 336 . When $\mathrm{HCl}$ concentration was 1 and $3 \mathrm{M}$, the extraction percentage of $\mathrm{Rh}$ increased with the increase of Alamine336 concentration. However, Alamine336 concentration has negligible effect on the extraction percentage of $\mathrm{Rh}$ at $5 \mathrm{M} \mathrm{HCl}$ concentration.

Fig. 8 shows the variation of the extraction percentage of Rh with Alamine336 concentration in the absence and presence of $\mathrm{SnCl}_{2}$. It is obvious that adding $\mathrm{SnCl}_{2}$ has a favorable effect
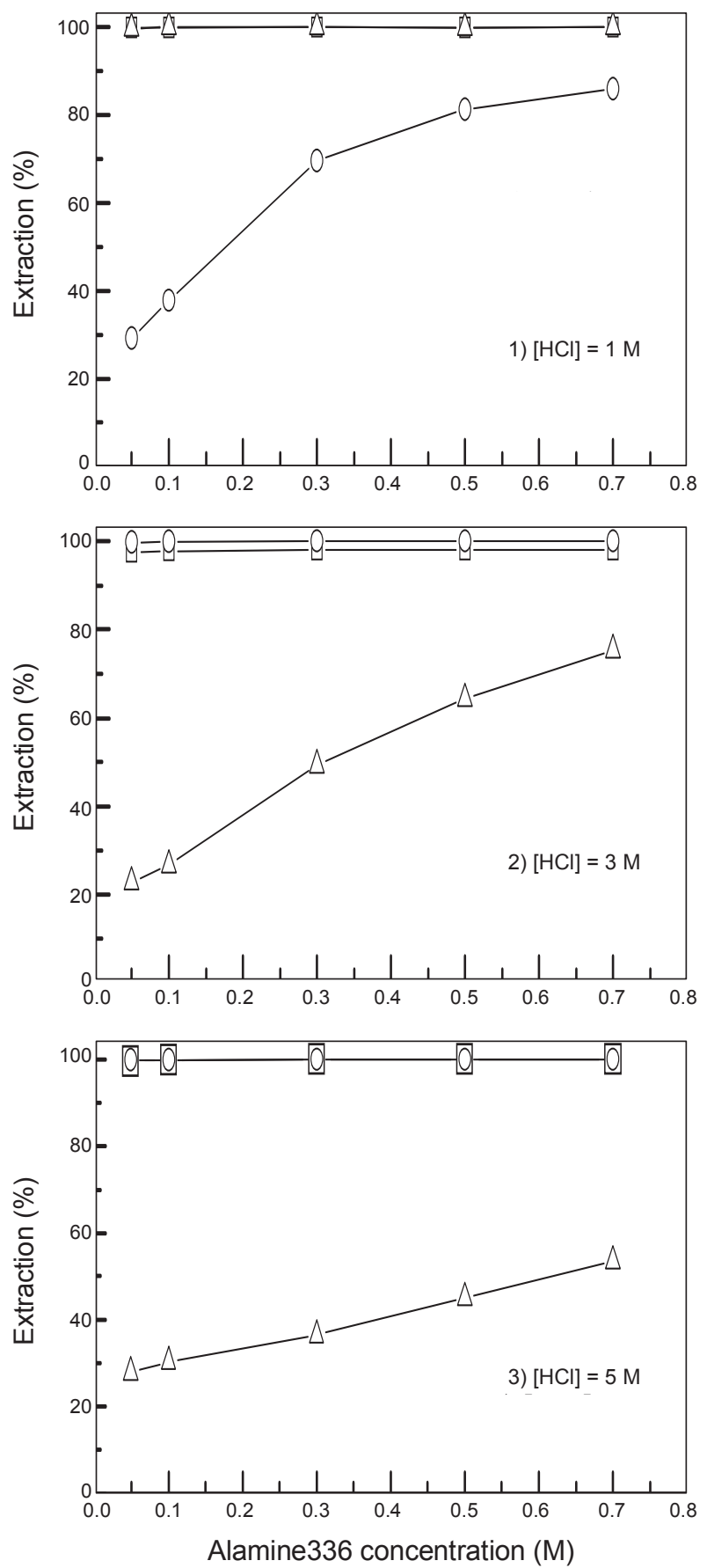

Figure 6. Effect of Alamine 336 concentration on the extraction \% of metals ad diffierent $\mathrm{HCl}$ concentration in the mixed solutions of $\mathrm{Pt}(\mathrm{IV})$ $\mathrm{Pd}(\mathrm{II})$ and $\mathrm{Rh}(\mathrm{III}) .\left(\left[\mathrm{PtCl}_{4}\right]_{\text {total }}=0.001 \mathrm{M},\left[\mathrm{PdCl}_{2}\right]_{\text {total }}=0.001 \mathrm{M}\right.$, $\left.\left[\mathrm{PdCl}_{3}\right]_{\text {total }}=0.001 \mathrm{M}\right)(-\square-: \mathrm{Pt}(\mathrm{IV}),-\mathrm{O}-\mathrm{Rd}(\mathrm{II}),-\triangle: \mathrm{Rh}(\mathrm{III}))$.

on the extraction of Rh. According to the literatures, rhodium is activated after adding $\mathrm{SnCl}_{2}$ and most of trivalent rhodium complexes are reduced to monovalent rhodium complexes by the oxidation of $\mathrm{Sn}(\mathrm{II})$ to $\mathrm{Sn}(\mathrm{IV})$, which is represented in Eqs. (5) and (6). ${ }^{5,6,14}$

$$
\begin{aligned}
& \mathrm{RhCl}_{6}{ }^{3-}+6 \mathrm{SnCl}_{3}{ }^{-} \\
& \quad=\left[\mathrm{Rh}\left(\mathrm{SnCl}_{3}\right)_{5}\right]^{4-}+\mathrm{SnCl}_{6}{ }^{2-}+3 \mathrm{Cl}^{-}
\end{aligned}
$$



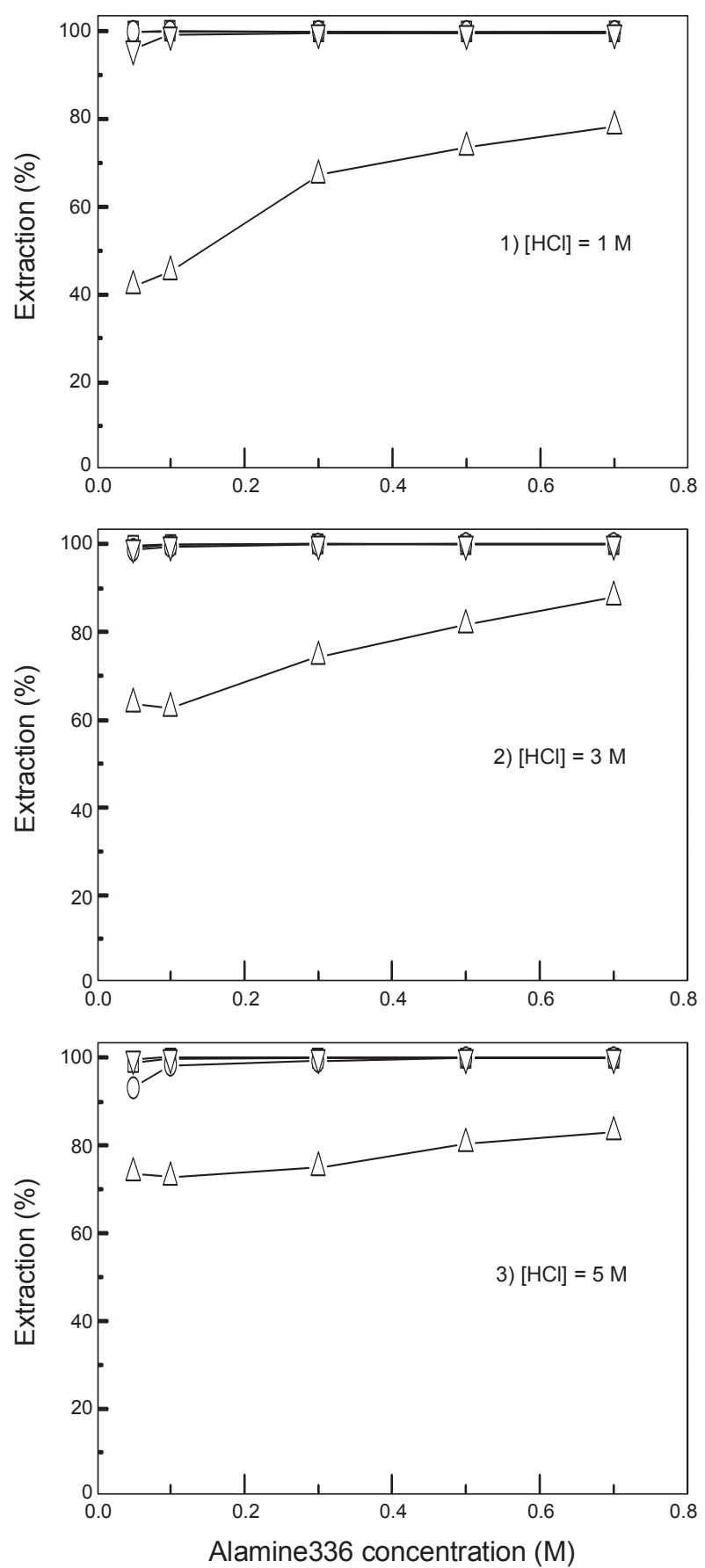

Figure 7. Effect of Alamine336 concentration on the extraction of metals from the mixed solutions of $\mathrm{Pt}(\mathrm{IV}) \mathrm{Pd}(\mathrm{II})$ and $\mathrm{Rh}$ (III) at diffierent $\mathrm{HCl}$ concentration in the presence of $\mathrm{SnCl}_{2}$. $\left(\left[\mathrm{PtCl}_{4}\right]_{\text {total }}=0.001 \mathrm{M}\right.$, $\left.\left[\mathrm{PdCl}_{2}\right]_{\text {total }}=0.001 \mathrm{M},\left[\mathrm{PdCl}_{3}\right]_{\text {total }}=0.001 \mathrm{M},\left[\mathrm{SnCl}_{2}\right]_{\text {total }}=0.01 \mathrm{M}\right)$ (- $\left.-: \mathrm{Pt}(\mathrm{IV}),-\bigcirc^{-}: \operatorname{Rd}(\mathrm{II}),-\triangle: \operatorname{Rh}(\mathrm{III}),-\nabla^{-}: \mathrm{Sn}(\mathrm{II})\right)$.

$$
\begin{aligned}
& \mathrm{RhCl}_{5}\left(\mathrm{H}_{2} \mathrm{O}\right)^{2-}+12 \mathrm{SnCl}_{3}{ }^{-} \\
& \rightarrow\left[\mathrm{Rh}\left(\mathrm{SnCl}_{3}\right)_{5}\right]^{4-}+\mathrm{SnCl}_{6}{ }^{2-}+6 \mathrm{SnCl}_{3}{ }^{-}+2 \mathrm{Cl}^{-}+\mathrm{H}_{2} \mathrm{O}
\end{aligned}
$$

In our experiment, the molar ratio of $\mathrm{Sn}$ to $\mathrm{Rh}$ was more than 10 , which value is enough to produce an activated rhodium solution. ${ }^{1}$ It is shown in Fig. 8 that the increase in the extraction percentage of $\mathrm{Rh}$ in the presence of $\mathrm{SnCl}_{2}$ was pronounced with the increase of $\mathrm{HCl}$ concentration.

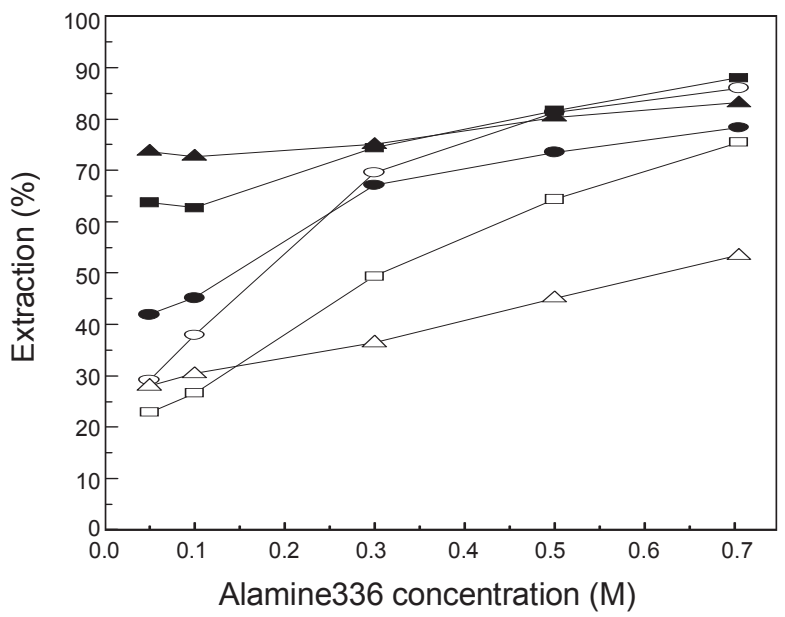

Figure 8. Effect of $\mathrm{SnCl}_{2}$ on the extraction of $\mathrm{Rh}$ (III) from the mixed solutions of $\mathrm{Pt}, \mathrm{Pd}$ and $\mathrm{Rh}$ at diffierent $\mathrm{HCl}$ concentration with respect to Alamine336 concentration. $\left(\left[\mathrm{PtCl}_{4}\right]_{\text {total }}=0.001 \mathrm{M},\left[\mathrm{PdCl}_{2}\right]_{\text {total }}=\right.$ $\left.0.001 \mathrm{M},\left[\mathrm{RhCl}_{3}\right]_{\text {total }}=0.001 \mathrm{M}\right)(-\mathrm{O}-: 1 \mathrm{M} \mathrm{HCl},-\square-3 \mathrm{M} \mathrm{HCl},-\triangle$ : $5 \mathrm{M} \mathrm{HCl},-:: 1 \mathrm{M} \mathrm{HCl},-: 3 \mathrm{M} \mathrm{HCl},-\mathbf{-}: 5 \mathrm{M} \mathrm{HCl}$, open is without $\mathrm{SnCl}_{2}$, solid is with $\mathrm{SnCl}_{2}$ ).

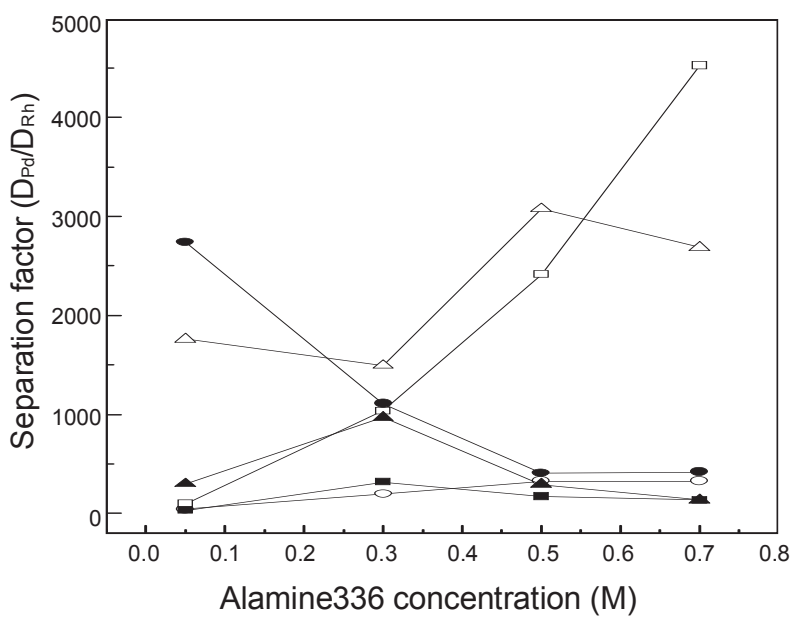

Figure 9. Separation factor for $\mathrm{Pt}(\mathrm{IV})$ and $\mathrm{Rh}(\mathrm{III})$ at different $\mathrm{HCl}$ concentration with respect to Alamine336 concentration. $\left(\left[\mathrm{PtCl}_{4}\right]_{\text {total }}=\right.$ $\left.0.001 \mathrm{M},\left[\mathrm{PdCl}_{2}\right]_{\text {total }}=0.001 \mathrm{M},\left[\mathrm{RhCl}_{3}\right]_{\text {total }}=0.001 \mathrm{M}\right)(-\mathrm{O}-: 1 \mathrm{M}$ $\mathrm{HCl}, \triangle: 3 \mathrm{M} \mathrm{HCl},-\square: 5 \mathrm{M} \mathrm{HCl},--: 1 \mathrm{M} \mathrm{HCl},-\frac{\boldsymbol{\Lambda}}{-} 3 \mathrm{M} \mathrm{HCl}$, - $5 \mathrm{M} \mathrm{HCl}$, open is without $\mathrm{SnCl}_{2}$, solid is with $\mathrm{SnCl}_{2}$ ).

Figs. 9 and 10 represent the variation in the separation factors of $\mathrm{D}_{\mathrm{Pt}} / \mathrm{D}_{\mathrm{Rh}}$ and $\mathrm{D}_{\mathrm{Pd}} / \mathrm{D}_{\mathrm{Rh}}$ at different $\mathrm{HCl}$ concentration in the presence and absence of $\mathrm{SnCl}_{2}$. When $\mathrm{HCl}$ concentration was $1 \mathrm{M}$, adding $\mathrm{SnCl}_{2}$ to the mixed solution of the three PGMs increased both of the separation factors ( $\mathrm{D}_{\mathrm{Pt}} / \mathrm{D}_{\mathrm{Rh}}$ and $\left.\mathrm{D}_{\mathrm{Pd}} / \mathrm{D}_{\mathrm{Rh}}\right)$. However, both of the separation factors in the absence of $\mathrm{SnCl}_{2}$ were much higher than those in the presence of tin chloride when $\mathrm{HCl}$ concentration was 3 and $5 \mathrm{M}$. This phenomena is due to the fact that adding $\mathrm{SnCl}_{2}$ to the mixed solution had a positive effect on the extraction of $\mathrm{Rh}$. Our results indicate that there are two routes to obtain $\mathrm{Rh}$ from the mixed chloride solutions containing $\mathrm{Pt}$ and $\mathrm{Pd}$. One is to extract all the three PGMs at high $\mathrm{HCl}$ concentration by adding $\mathrm{SnCl}_{2}$. The other route is to extract both $\mathrm{Pt}$ and $\mathrm{Pd}$ from the mixed solution at weak $\mathrm{HCl}$ concentration in 


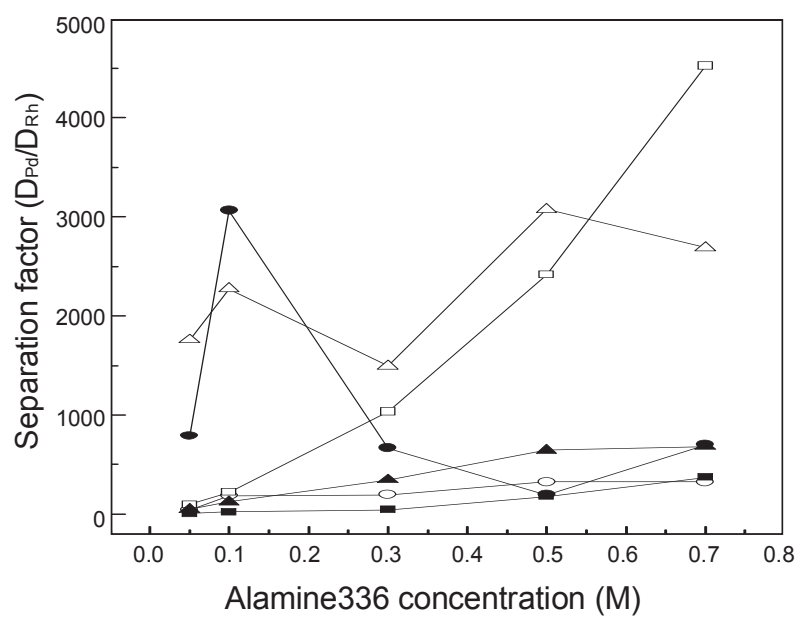

Figure 10. Separation factor for $\mathrm{Pd}(\mathrm{II})$ and $\mathrm{Rh}$ (III) at different $\mathrm{HCl}$ concentration with respect to Alamine336 concentration. $\left(\left[\mathrm{PtCl}_{4}\right]_{\text {total }}=\right.$ $\left.0.001 \mathrm{M},\left[\mathrm{PdCl}_{2}\right]_{\text {total }}=0.001 \mathrm{M},\left[\mathrm{RhCl}_{3}\right]_{\text {total }}=0.001 \mathrm{M}\right)\left(-\mathrm{O}^{-}: 1 \mathrm{M}\right.$ $\mathrm{HCl}, \triangle: 3 \mathrm{M} \mathrm{HCl},-\square: 5 \mathrm{M} \mathrm{HCl},-\longrightarrow: 1 \mathrm{M} \mathrm{HCl},-\boldsymbol{\triangle}: 3 \mathrm{M} \mathrm{HCl}$, -: $5 \mathrm{M} \mathrm{HCl}$, open is without $\mathrm{SnCl}_{2}$, solid is with $\mathrm{SnCl}_{2}$ ).

the absence of $\mathrm{SnCl}_{2}$ and leave the rhodium in the chloride solution. In the former route, the three PGMs which were extracted into Alamine 336 could be separated by employing scrubbing and stripping.

\section{Conclusions}

Solvent extraction behavior of Pd (II), Pt (IV) and Rh (III) was investigated from the mixed chloride solution with Alamine336 in different concentration of $\mathrm{HCl}$ solutions. Most of Pt and $\mathrm{Pd}$ could be extracted from the mixed chloride solution by adjusting $\mathrm{HCl}$ and Alamine 336 concentration. However, the extraction percentage of $\mathrm{Rh}$ was found to be dependent on the extraction conditions and decreased with the increase of $\mathrm{HCl}$ concentration. Separation of $\mathrm{Rh}$ from the mixed solution containing $\mathrm{Pt}$ and $\mathrm{Pd}$ would be possible by extracting $\mathrm{Pt}$ and $\mathrm{Pd}$ at high $\mathrm{HCl}$ concentration. Adding $\mathrm{SnCl}_{2}$ to the mixed solutions of the three platinum group metals has a favorable effect on the extraction of $\mathrm{Rh}$, while the extraction of Pt and Pd was not affected. Our results could be utilized in developing a strategy to recover rhodium from the mixed solutions of platinum and palladium.

Acknowledgments. This work was supported by a grant operated by KEITI of the Ministry of Environment of Korea. The authors would like to thank for the financial support.

\section{References}

1. Rao, C. R. M.; Reddi, G. S. Trends in the Analytical Chemistry 2000, $19,565$.

2. Benguerel, E.; Demopoulos, G. P.; Harris, G. B. Hydrometallurgy 1996, 40, 135

3. Lee, M. S; Lee, J. Y.; Rajesh Kumar J.; Kim J. S.; Sohn J. S. Materials Transactions 2008, 49, 2823.

4. Zou, L.; Chen, J.; Pan, X. Hydrometallurgy 1998, 50, 193.

5. Mhaske, A. A.; Dhadke, P. M. Hydrometallurgy 2001, 61, 143.

6. Shafiqul, A. M.; Inoue, K. Hydrometallurgy 1997, 46, 373.

7. Levitin, G.; Schmuckler, G. Reactive \& Functional Polymers 2003, $54,149$.

8. Mhaske, A.; Dhadke, P. Separation Science and Technology 2001, $36,3253$.

9. Nowottny, C.; Halwachs, W.; Schügerl, K. Separation and Purification Technology 1997, 12, 135.

10. Lee, M. S.; Lee, K. J.; Oh, Y. J. Mater. Trans. 2004, 45, 2364.

11. Gai, H. F.; Shen, J. L.; Hughes, M. A. Hydrometallurgy 1990, 25, 293.

12. Filiz, M. Hydrometallurgy 2007, 87, 58.

13. Sayar, N.A.; Filiz, M.; Sayar, A. A. Hydrometallurgy 2007, 86, 27.

14. Iwasaki, S.; Nagai, T.; Miki, E.; Mizumachi, K.; Ishimori, T.; Chem. Bull. Soc. Jpn 1984, 57, 386. 